\title{
Introduced tree and shrub species for sustainable landscape compositions in the urban conditions
}

\author{
Zoya Ozherelieva ${ }^{1 *}$, Olga Emelianova ${ }^{1}$, and Andrey Firsov ${ }^{1}$ \\ ${ }^{1}$ Russian Research Institute of Fruit Crop Breeding (VNIISPK), Zhilino, 1, 302530, Orel district, Orel \\ region, Russia
}

\begin{abstract}
Low temperature is one of the most significant limiting factors determining the distribution of tree species. Evaluation of the degree of freezing of tree and shrub species is of great importance for decorative gardening. Plants freeze a lot not only in harsh winters, but also during prolonged thaws with a subsequent drop in temperature, which negatively affects their ornamentation. In this regard, one of the main ways to preserve the ornamental and plant biodiversity of city parks in a temperate continental climate is to replenish existing plantings with frost-resistant tree species. It is the first study of the frost resistance of introduced trees and shrubs, which was made to isolate species adapted to the winter conditions of the temperate continental climate to form stable landscape compositions in urban parks. Based on the results of artificial freezing, species of woody plants with high frost resistance were selected: Betula kelleriana, Betula raddeana, Staphylea pinnata, Cotinus Coggygria and Pinus pallasiana. The above species of wood are recommended for sustainable landscape design in the city.
\end{abstract}

\section{Introduction}

Urban development causes an increase in the exploitation of natural resources to a greater extent, which leads to instability of the ecological potential of plants. The attitude towards sustainable development of the city's ecology underlines the role of landscaping, and to achieve this goal, the "green zone" is considered one of the most essential tools for improving urban development [1]. Green zones play a very important role in urban environments and create a link between natural and human factors. It has been argued that urban trees provide numerous environmental and social benefits to the quality of life of our urban community [2]. Firstly, street greens help create a visual image of the city and provide additional public space, and secondly, it ecologically links large green spaces (parks, squares, etc.) and improves the microclimate [3].

\footnotetext{
* Corresponding author: ozherelieva@,vniispk.ru
} 
Trees have always been exposed to adverse weather conditions. Frost and thaw, high temperatures, and drought lead not only to deceleration of growth, but also increase mortality of trees and shrubs.

In habitats exposed to frost (i.e., moderate to boreal areas), perennials must cope with low-temperature stress every winter [4]. Wooden species originating from locations close to the Atlantic Ocean (The Netherlands, the UK, Denmark) tended to be less frost resistant than more continental wooden species (from Norway, Sweden, Finland, Poland and Russia) [4].

Frost is one of the worst adverse abiotic stresses a plant may encounter, and frost exposure is a limiting factor for the diversity of many species in temperate regions $[5,6]$. Cold acclimatization is a complex process, which involve $s$ numerous physiological mechanisms under the influence of frost [7]. In the middle of winter, damage to the bark and cambium is rarely observed in woody plants, since these tissues are characterized by a higher frost resistance. This is due toward the circumstance that the cells of the cortex and cambium are more dehydrated and this protects these tissues from intracellular ice freezing [8]. It is after harsh winters that the wood and core are mostly damaged. Damage to wood is associated with homogeneous crystallization of deeply super cooled water. Severe freezing of wood results in browning due to the accumulation of gum-like brown substances, which clog the vessels, that impedes the movement of nutrients and causes the death of plants [7].

In nature, freezing or death of trees is observed not only in harsh winters, but also with a sharp decrease in temperature during thaws $[6,9]$. During thaws, a violation of the deep dormancy of trees is observed, and as a result of this, we can observe natural freezing or death of trees with a further decrease in temperature. The ability of plants to resist frost is of great importance against the prolonged thaws [10]. When the temperature rises for three or more days (thaw) in winter, the physiological state of the trees changes and their frost resistance decreases [11].

As a result, when choosing the assortment of woody plants for creating sustainable landscape compositions, one of the main properties of plants that determine their widespread adoption in culture in a temperate continental climate is their frost resistance [11]. Frost resistance is one of the main indicators of the recommendation of tree species for use in landscaping and afforestation in a specific climate zone. The level of frost resistance significantly affects many characteristics of plants, such as decorativeness, flowering, productivity, life expectancy, etc. In plants, organs and tissues differ in frost resistance.

Since low temperature is a key environmental factor that determines the evolution and distribution of plants, the purpose of this work is to study frost resistance of adapted introduced tree species and to select them for the formation of sustainable urban landscape compositions.

\section{Materials and methods}

\subsection{Field of study}

The study of frost resistance of 15 species of wood of various ecological and geographical origin was approved out on the foundation of the laboratory of physiology of resistance of fruit plants and the VNIISK arboretum in 2015-2017. The institute is situated in the central part of the Central Russian Upland (53 $3^{\circ}$ north latitudes, $36^{\circ}$ east longitude). VNIISPK is located $368 \mathrm{~km}$ south-west of Moscow. 
The climate in the Oryol region is temperate continental. The average annual temperature is $4-5^{\circ} \mathrm{C}$. The average daily temperature of the January is $-10^{\circ} \mathrm{C}$. The absolute minimum temperature over the past 20 years has been $-39,3^{\circ} \mathrm{C}$. The average dates of autumn frosts happen at the end of September. The average frost-free period is 135-150 days. On average, precipitation ranges from 490 to $580 \mathrm{~mm}$ per year. Snow cover reaches its maximum depth from mid-February to mid-March. Its average thickness is $20-25 \mathrm{~cm}$.

\subsection{Material}

Urban plant habitats are very similar. Therefore, the floristic compositions in urbanized territories of different climatic zones also become very similar. Thus, $15 \%$ of plant species are common to all European cities whereas this indicator is much higher for the centers of these cities - up to $50 \%$ [12].

The leading place in the landscaping of the Russian cities in the temperate zone is occupied by deciduous species whereas coniferous species account for a small share [12]. The largest share is represented by deciduous trees - Tilia cordata, Acer platanoides, Populus balsamifera, Fraxinus pennsylvanica, Fraxinus excelsior, Sorbus aucuparia, Ulmus laevis and Betula pendula. The share of other species is less than $1 \%$. In the city can be found species such Betula pendula, Quercus pedunculata, Acer negundo, Aesculus hippocastanum, Tilia platyphyllos and Betula pubescens. Coniferous trees include Pinus sylvestris, Picea excels, Picea pungens, Picea canadensis and Larix decidua [12, 13]. Of the deciduous shrubs, the following are more common: Cornus alba, Symphoricarpos albus, Rosa rugosa, Physocarpus opulifolium, Syringa vulgaris and Syringa josikaea, Acer ginnala, Berberis vulgaris and Spiraea vanhouttei. Of the coniferous shrubs in the urban environment, only Juniperus sabina and different forms of Thuja occidental are often found.

The objects of research were 15 woody species of different ecological and geographical origin (table 1). The studied tree species are introduced in the Oryol region. Much attention to the introduced species in the gardening practice is due to the circumstance that in an urbanized environment, when the environmental conditions are sufficiently compliant with the biological characteristics and ecological properties of the introduced species, they often turn out to be more stable (they exhibit adaptive abilities to local soil and climatic conditions) being more durable than local species. Accordingly, their use in the design of landscape compositions will provide a significant increase in the aesthetic and sanitaryhygienic properties of urban green spaces, will help to reduce the cost of their maintenance, and will expand the genetic biodiversity of modern urban parks and squares.

The annual shoots of 15 ornamental species of wood were taken at the end of November for all variants of artificial freezing. Annual sprouts were cut at the rate of 10 pieces of each species. Then they were divided into 5 annual shoots for each variant of the experiment. One annual shoot is one repetition; each variant of the experiment was 5 repetitions. The base of the annual shoots was wrapped with a damp cloth to prevent them from drying out and placed in plastic bags. The experimental material was stored at $-3^{\circ} \mathrm{C}$ until the start of the experiment.

The studying tree species are of different ecological and geographical origin and are distinguished by a beautiful crown shape and color of the bark, a variety of flower colors, openwork foliage and evergreen needles, a bright autumn outfit. This species can be used both for single planting and in small groups. 
Table 1. Objects of the research.

\begin{tabular}{|c|c|}
\hline Ecological and geographical origin & Species \\
\hline $\begin{array}{c}\text { Altai region (Southeast of Western Siberia, } \\
\text { Russia) }\end{array}$ & Betula kelleriana Sukacz. \\
\hline Crimea, northern part Black Sea coast & Pinus pallasiana Lamb. \\
\hline Far East, North-East China, Northern Korea & Armeniaca manshurica (Maxim.) Skvortz. \\
\hline Eastern North America & $\begin{array}{c}\text { Acer rubrum L. } \\
\text { Acer saccharinum L. }\end{array}$ \\
\hline European Russia & Betula pendula f. carelica Hort. \\
\hline Japan & Acer japonicum Thunb. \\
\hline Mediterranean & $\begin{array}{c}\text { Staphylea pinnata L. } \\
\text { Betula raddeana Trautv. } \\
\text { Picea omorica (Pancic) Purcyne. }\end{array}$ \\
\hline Northern and Central America & $\begin{array}{c}\text { Mahonia aquifolium (Pursch) Nutt. } \\
\text { Mahonia pinnata (Lag) Feddl } \\
\text { Betula lenta L. }\end{array}$ \\
\hline South Western Europe, Balkans, Asia & Cotinus coggygria Scop. \\
\hline Western Europe & Fagus silvatica L. \\
\hline
\end{tabular}

\subsection{Method}

The study of frost resistance of woody species in a temperate continental climate was carried out by the method of artificial freezing.

\subsubsection{Simulation of autumn hardening of plants}

Hardening was simulated in the Espec PSL-2KPH climate chamber (Japan). Hardening was carried out in two stages. The temperature in the growth cabinet was first lowered to $-5^{\circ} \mathrm{C}$ and the annual shoots of the studied tree species were kept at this temperature for 5 days. Then the temperature was reduced to $-10^{\circ} \mathrm{C}$ and the annual shoots were hardened off for -5 days.

\subsubsection{The first mode of artificial freezing}

In January, after hardening off $\left(-5^{\circ} \mathrm{C}\right.$ for 5 days; $-10^{\circ} \mathrm{C}$ for 5 days $)$, winter frost $-40^{\circ} \mathrm{C}$ was simulated. The temperature decreased at a rate of $-5^{\circ} \mathrm{C}$ per hour. The duration of freezing at $-40^{\circ} \mathrm{C}$ was 8 hours (fig. 1). Growing of annual shoots was carried out in vessels with water. Assessment of damage to the sprouts and tissues of annual shoots was carried out after 5 days using a MBS-2 binocular microscope. 
Table 2. The main phenological phases of development of the studied tree species.

\begin{tabular}{|c|c|c|c|c|c|c|c|}
\hline \multirow[b]{2}{*}{ Species } & \multicolumn{7}{|c|}{ Deciduous trees and shrubs } \\
\hline & $\begin{array}{c}\text { Beginnin } \\
\text { g of bud } \\
\text { break }\end{array}$ & $\begin{array}{c}\text { Beginning } \\
\text { of } \\
\text { flowering }\end{array}$ & \begin{tabular}{|c|} 
End of \\
flowerin \\
$\mathrm{g}$
\end{tabular} & $\begin{array}{c}\text { Fruit } \\
\text { setting }\end{array}$ & $\begin{array}{l}\text { Fall of } \\
\text { ripe } \\
\text { fruits }\end{array}$ & $\begin{array}{c}\text { Colouring } \\
\text { of leaves }\end{array}$ & $\begin{array}{l}\text { Fall of } \\
\text { leaves }\end{array}$ \\
\hline $\begin{array}{l}\text { Armeniaca } \\
\text { manshurica }\end{array}$ & $02.05 \pm 5$ & $23.04 \pm 4$ & $29.04 \pm 2$ & $18.05 \pm 4$ & $31.07 \pm 8$ & $09.09 \pm 9$ & $27.09 \pm 8$ \\
\hline Betula lenta & $23.04 \pm 7$ & $20.04 \pm 5$ & $30.04 \pm 4$ & $21.05 \pm 3$ & $18.10 \pm 9$ & $28.08 \pm 6$ & $18.10 \pm 9$ \\
\hline $\begin{array}{c}\text { Betula } \\
\text { pendula }\end{array}$ & $27.04 \pm 6$ & $01.05 \pm 5$ & $06.05 \pm 4$ & $23.05 \pm 3$ & $05.07 \pm 6$ & $23.09 \pm 6$ & $11.10 \pm 6$ \\
\hline $\begin{array}{l}\text { Betula } \\
\text { kelleriana }\end{array}$ & $01.05 \pm 6$ & $04.05 \pm 6$ & $08.05 \pm 6$ & $17.05 \pm 4$ & $12.07 \pm 7$ & $07.09 \pm 8$ & $02.10 \pm 5$ \\
\hline $\begin{array}{l}\text { Betula } \\
\text { raddeana }\end{array}$ & $20.04 \pm 5$ & $24.04 \pm 3$ & $06.05 \pm 5$ & $19.05 \pm 3$ & $29.07 \pm 7$ & $14.09 \pm 7$ & $15.10 \pm 6$ \\
\hline $\begin{array}{l}\text { Fagus } \\
\text { silvatica }\end{array}$ & $26.04 \pm 3$ & $02.05 \pm 4$ & $08.05 \pm 7$ & $29.05 \pm 6$ & $17.10 \pm 9$ & $08.10 \pm 8$ & $22.10 \pm 8$ \\
\hline $\begin{array}{l}\text { Staphylea } \\
\text { pinnata }\end{array}$ & $03.05 \pm 4$ & $10.05 \pm 9$ & $20.05 \pm 7$ & $06.06 \pm 5$ & $08.09 \pm 6$ & $21.09 \pm 8$ & $18.10 \pm 4$ \\
\hline $\begin{array}{l}\text { Acer } \\
\text { rubrum }\end{array}$ & $25.04 \pm 6$ & $27.04 \pm 8$ & $10.05 \pm 6$ & $17.05 \pm 5$ & $12.07 \pm 7$ & $03.09 \pm 5$ & $08.10 \pm 6$ \\
\hline $\begin{array}{l}\text { Acer } \\
\text { saccharinum }\end{array}$ & $18.04 \pm 6$ & $20.04 \pm 8$ & $30.04 \pm 7$ & $09.05 \pm 4$ & $19.05 \pm 5$ & $12.09 \pm 7$ & $05.10 \pm 6$ \\
\hline $\begin{array}{l}\text { Acer } \\
\text { japonicum }\end{array}$ & $23.04 \pm 3$ & $04.05 \pm 6$ & $15.05 \pm 5$ & $19.05 \pm 4$ & $27.10 \pm 5$ & $11.09 \pm 5$ & $06.10 \pm 7$ \\
\hline $\begin{array}{l}\text { Mahonia } \\
\text { aquifolium }\end{array}$ & $22.04 \pm 4$ & $25.04 \pm 7$ & $07.05 \pm 8$ & $08.05 \pm 3$ & $07.09 \pm 7$ & \multicolumn{2}{|c|}{ evergreen shrub } \\
\hline $\begin{array}{l}\text { Mahonia } \\
\text { pinnata }\end{array}$ & $14.04 \pm 5$ & $03.05 \pm 7$ & $10.05 \pm 7$ & $19.05 \pm 3$ & $28.08 \pm 9$ & \multicolumn{2}{|c|}{ evergreen shrub } \\
\hline $\begin{array}{l}\text { Cotinus } \\
\text { coggygria }\end{array}$ & $05.05 \pm 4$ & $24.05 \pm 5$ & $02.06 \pm 3$ & $27.06 \pm 6$ & $11.08 \pm 4$ & $27.09 \pm 4$ & $30.10 \pm 9$ \\
\hline \multirow[b]{2}{*}{ Species } & \multicolumn{7}{|c|}{ Coniferous trees } \\
\hline & \multicolumn{2}{|c|}{$\begin{array}{l}\text { Beginning of bud } \\
\text { break }\end{array}$} & $\begin{array}{c}\text { Beginnin } \\
\text { of poller } \\
\text { dispersio } \\
\end{array}$ & \multicolumn{2}{|c|}{\begin{tabular}{c|c} 
End of pollen \\
dispersion
\end{tabular}} & $\begin{array}{l}\text { Cones } \\
\text { formation }\end{array}$ & $\begin{array}{l}\text { Complete } \\
\text { maturation } \\
\text { of cones }\end{array}$ \\
\hline $\begin{array}{l}\text { Picea } \\
\text { omorica }\end{array}$ & \multicolumn{2}{|c|}{$26.04 \pm 7$} & $02.05 \pm 4$ & \multicolumn{2}{|c|}{$09.05 \pm 4$} & $30.05 \pm 3$ & $03.11 \pm 4$ \\
\hline $\begin{array}{l}\text { Pinus } \\
\text { pallasiana }\end{array}$ & \multicolumn{2}{|c|}{$10.05 \pm 8$} & $18.05 \pm 5$ & \multicolumn{2}{|c|}{$24.05 \pm 6$} & $04.06 \pm 5$ & $30.09 \pm 3$ \\
\hline
\end{tabular}

* average long-term date of the phenophase onset with a possible deviation ( \pm ) in years 


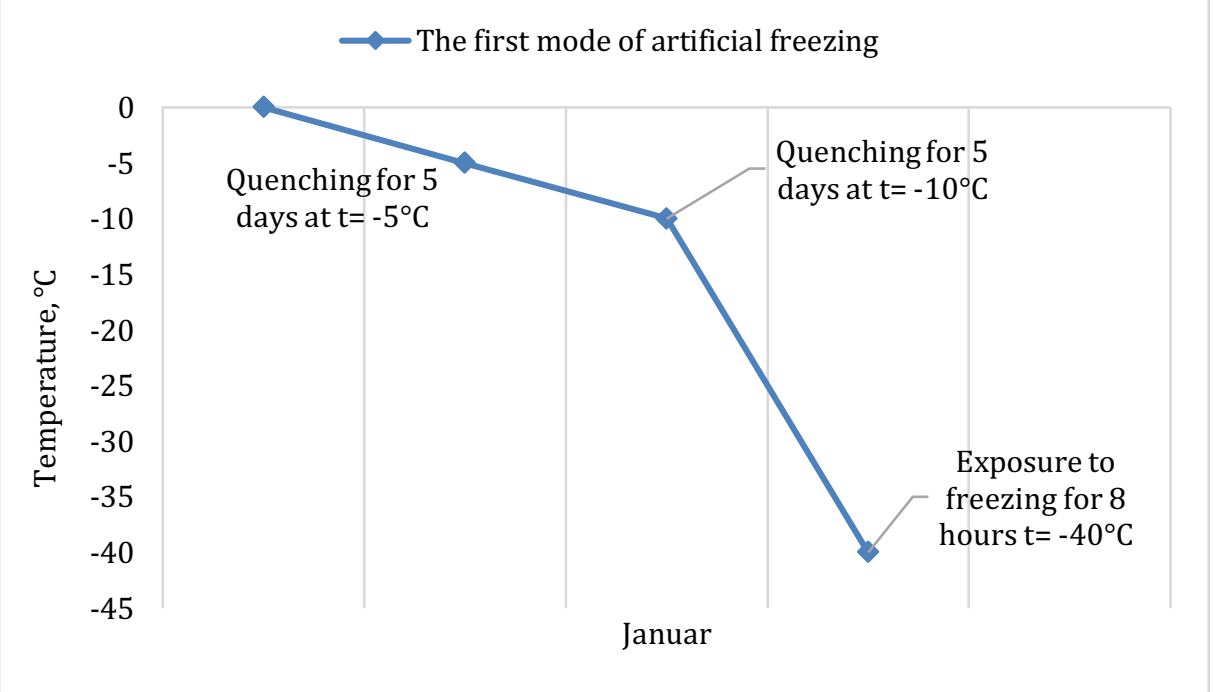

Fig. 1. The first model of artificial freezing.

\subsubsection{The second mode of artificial freezing}

In February, after hardening $\left(-5^{\circ} \mathrm{C}\right.$ for 5 days; $-10^{\circ} \mathrm{C}$ for 5 days), a three-day thaw $+2^{\circ} \mathrm{C}$ was simulated, then followed by a decrease in temperature to $-25^{\circ} \mathrm{C}$. The temperature decreased at a rate of $-5^{\circ} \mathrm{C}$ per hour. The duration of freezing at $-25^{\circ} \mathrm{C}$ was 8 hours (fig. 2). The growth of annual shoots after freezing was carried out in vessels with water. Assessment of damage to the sprouts and tissues of annual shoots was carried out after 5 days using a MBS-2 binocular microscope.

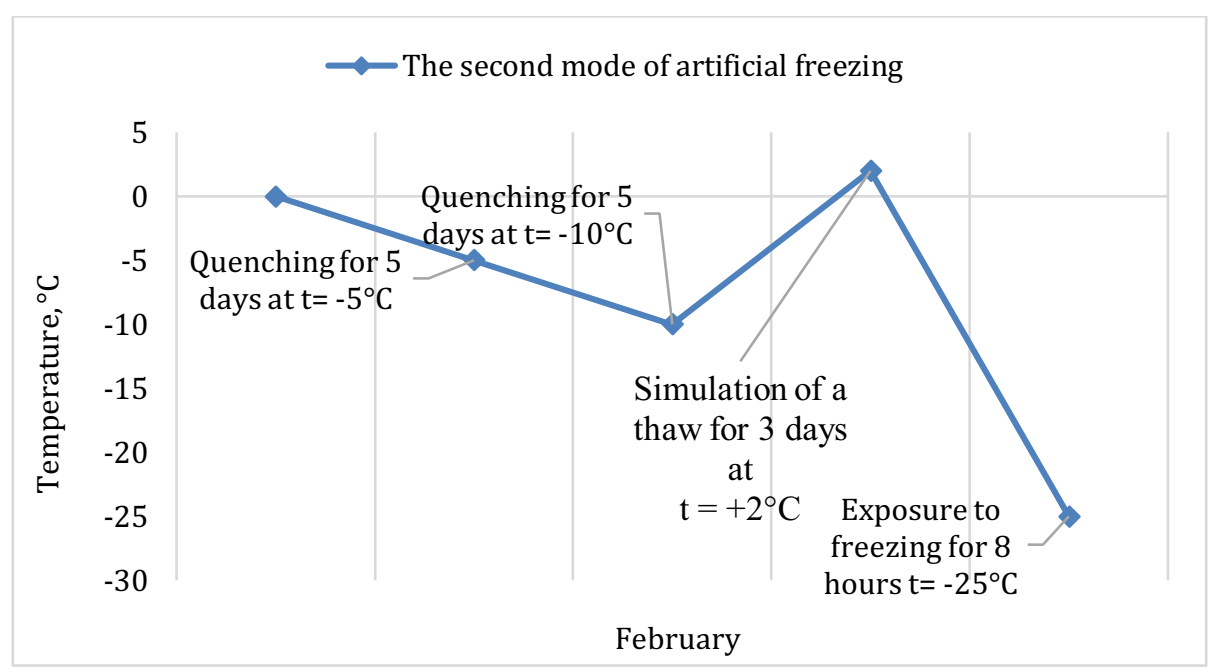

Fig. 2. The second model of artificial freezing.

\subsubsection{Degree of Damages}


Damage was evaluated depending on the degree of discoloration of tissues and buds of annual shoots in longitudinal and transverse sections according to the following scale: $0,0-$ no damage; 1,0 point - minor damage, up to $10 \%$ of the fabric changed color to light yellow; 2,0 point - reversible damage, up to $25 \%$ of the fabric changes color to light brown; 3,0 point - average damage, up to $30-40 \%$ of the total tissue area of the annual shoot and sprouts changed color to brown; 4,0 point - tissues of the annual shoot and sprouts were severely damaged, the color of the tissues changed to brown by more than $50 \%$ of the cut of the annual shoot and sprouts; 5,0 points - tissues of the annual shoot and sprouts died and were dark brown.

\subsubsection{Statistical analysis}

All results were verified using one-way ANOVA analysis of variance (version 22, SPSS). The variance analysis was carried constructed using the Microsoft Office Excel 2016 software. The Student's (t-test) criterion was used to determine the level of significance of the features at the level of significance $p<0,05$. To identify differences between tree species, the smallest average difference was calculated (LSD 05 ).

\section{Results}

\subsection{The first mode of artificial freezing}

In January, high frost resistance was demonstrated by: Betula kelleriana, Betula raddeana, Staphylea pinnata, Cotinus coggygria, Acer saccharinum, Pinus pallsiana after temperature exposure of $-40^{\circ} \mathrm{C}$. These species had minor damage to the sprouts and wood of annual shoots, not more than 1,0 point. At the same time, the bark was not damaged by a temperature of $-40^{\circ} \mathrm{C}$. In the species Pinus pallsiana, growing in the Mediterranean climate, the sprouts and bark in January withstood a temperature drop of $-40^{\circ} \mathrm{C}$ without damage. In Pinus pallsiana, the wood had minor damage - 0,2 points. At the same time, plants from more northern latitudes (Betula lenta, Betula pendula $f$. Carelica and Acer japonicum) showed frost resistance with reversible damage to the sprouts from 1,1 to 2,0 points and slight damage to the wood (up to 1,0 point). At the same period, the wood in the studied species of birch was not damaged. Acer rubrum wood suffered from a temperature of $-40^{\circ} \mathrm{C}$ in January to a greater extent - up to 2,0 points. Picea omorica, despite its Mediterranean origin, withstood temperatures of $-40^{\circ} \mathrm{C}$ with reversible damage to the sprouts (2.0 points), bark (1.3 points) and minor damage to the wood (0,9 points). Fagus sylvatica and Armeniaca manshurica showed an average level of frost resistance of sprouts, bark and wood of annual shoots. The degree of damage to the sprouts ranged from 2,7 to 3,0 points, the bark was damaged by frost from 1,5 to 2,5 points, and wood - 2,2 points. Weak frost resistance was found in Mahonia aquifolium and Mahonia pinnata in mid-winter at $\mathrm{t}=$ $40^{\circ} \mathrm{C}$. At the same time, the sprouts of Mahonia species died, the bark was severely frozen, and the wood had reversible damage of no more than 2,0 points (fig. 3). The findings are consistent with other studies. According to scientists from the Main Botanical Garden, Mahonia, which grows in nature in the southern regions, is often subjected to freezing in Central Russia [14]. According to ANOVA, a significant difference between the studied species was noted at a 5\% significance level. 

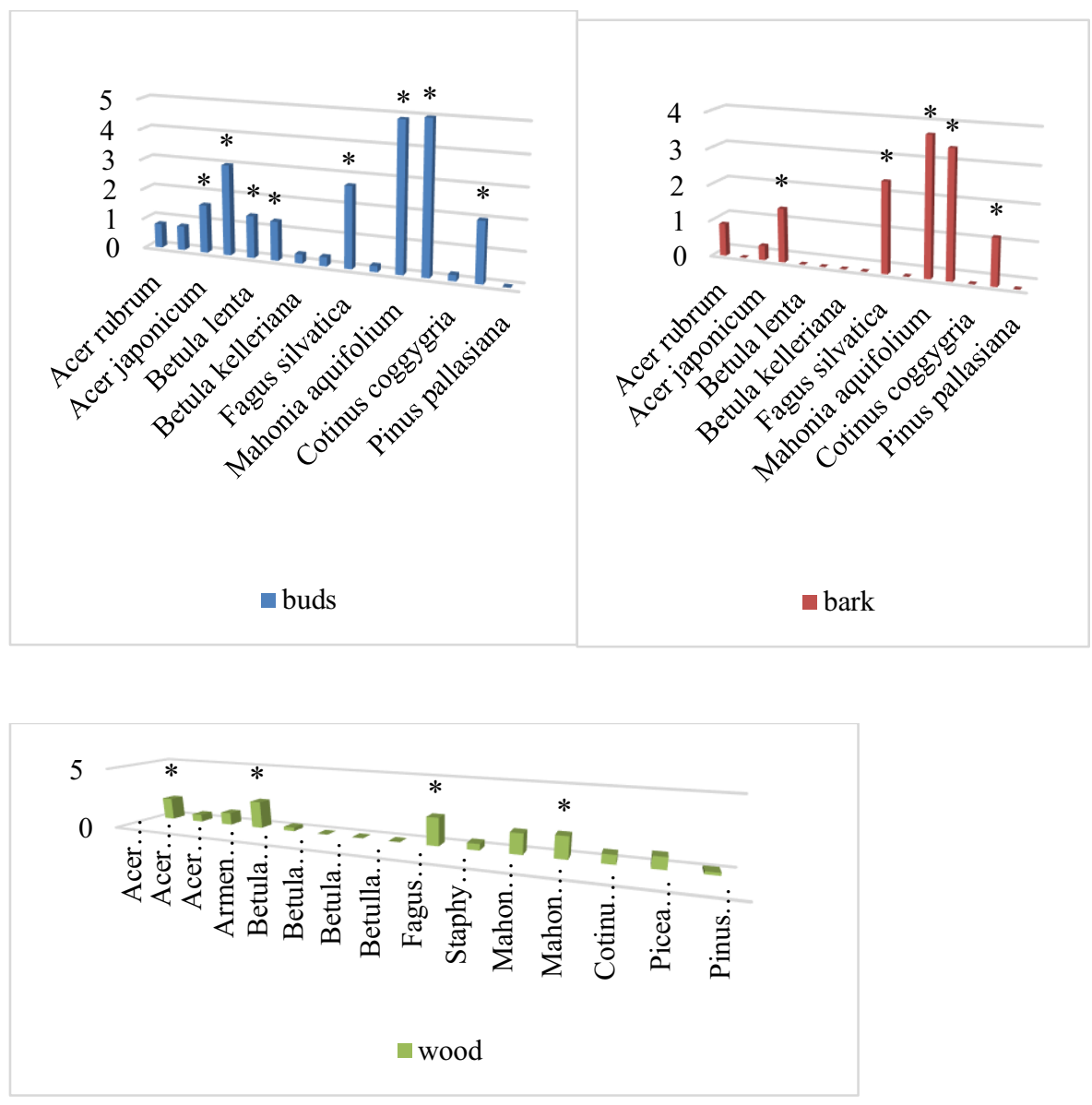

* - significantly at a significance level of $p<0,05$

Fig. 3. Results of artificial freezing of species of ornamental trees and shrubs

\subsection{The second mode of artificial freezing}

The ability of plants to resist frost is of great importance against the prolonged thaws [15]. After simulating a thaw of $+2{ }^{\circ} \mathrm{C}$ and the subsequent sharp drop in temperature to $-25^{\circ} \mathrm{C}$ in February, Staphylea pinnata, Cotinus coggygria and Picea omorica, having a Mediterranean ecological and geographical origin, preserved the sprouts and tissues of annual shoots without damage.

In February, other species - Armeniaca manshurica, Betula kelleriana, Betula raddeana, Acer rubrum and Pinus pallasiana also showed high frost resistance of the sprouts and tissues with minor damage no more than 1,0 point. Betula lenta, Betula pendula $f$. Carelica and Acer saccharinum showed frost resistance with reversible damage to the sprouts (not more than 2,0 points). The average frost resistance of the sprouts at $-25^{\circ} \mathrm{C}$ after a three-day thaw of $+2^{\circ} \mathrm{C}$ was observed in Fagus sulvatica, Acer japonicum and Mahonia pinnata. Mahonia aquifolium showed the lowest frost resistance of sprouts, bark, and wood after thawing at $\mathrm{t}=-25^{\circ} \mathrm{C}$ (fig. 4). According to ANOVA, a significant difference between the 15 studied species of ornamental trees and shrubs was noted at a $5 \%$ significance level. 


\section{Discussion}

Climate is one of the most significant factors affecting plant distribution. Various restrictive factors, such as drought, insect and fungus damages, extreme heat and cold, soil wetness, day length, nutrient deficiencies, salinity and air pollution affect plant growth. Plants are very well adapted to the extreme conditions existing within their natural range of occurrence; however, they are likely to suffer when they are grown outside these regions.

Out of all factors global that potentially limit geographical distribution ranges of plants, minimum temperatures are considered the most important [8]. In particular, frost is thought to be the reason of northern and eastern distribution range boundaries of plant species in Europe [16]. For example, Fagus sylvatica does not occur in regions with a mean temperature in January below $-3^{\circ} \mathrm{C}$ [17].

Resistance to low temperatures operates at the species level, and the distribution of species is strongly related to their resistance to winter frosts. Species from cold climates are likely to have high resistance to frost while those from warmer climates are less frost hardy. Woody plants in these areas are frequently exposed to conditions that can result in frost damage $[5,8]$. One of the consequences of climate change plants will have to face is the potential occurrence of milder winters with less snow. In the last 20-25 years, the frequency of thaws and their temperatures have increased due to global warming. In winter, tree species may suffer from sudden cold snaps after deep and prolonged thaws. The situation is aggravated by the fact that recurrent frosts inflict damage primarily to the most important organs (buds) and tissues (bark, cambium) of trees [7]. In February and March, in conditions of a temperate continental climate, prolonged thaws have recently become more frequent, which leads to a violation of the deep dormancy of trees. The ability of plants to withstand frost during thaws is essential during prolonged thaws. It should be noted that the potential for resistance to low temperatures is determined not only by the genotype, but also largely depends on the prevailing environmental factors and growing conditions [18].

Therefore, the degree of freezing in the same species can fluctuate over the years. Among the species studied by us, Betula kelleriana, Betula raddeana, Staphylea pinnata, Cotinus Coggygria and Pinus pallasiana were characterized by stable frost resistance of sprouts and tissues of annual shoots by years (2015-2017). These species, with the exception of Betula kelleriana, which grows in the south of Altai, are of Mediterranean ecological and geographical origin. They have been classified as woody species with high frost resistance. Accordingly, the selected species are recommended as an additional assortment for landscape design of squares, streets, parks and alleys of cities in a temperate continental climate. Woody plants are an essential part of the urban landscape and are also of great importance in the lives of people. They purify and moisturize the air of cities, reduce noise and wind intensity, change the radiation and temperature conditions. 

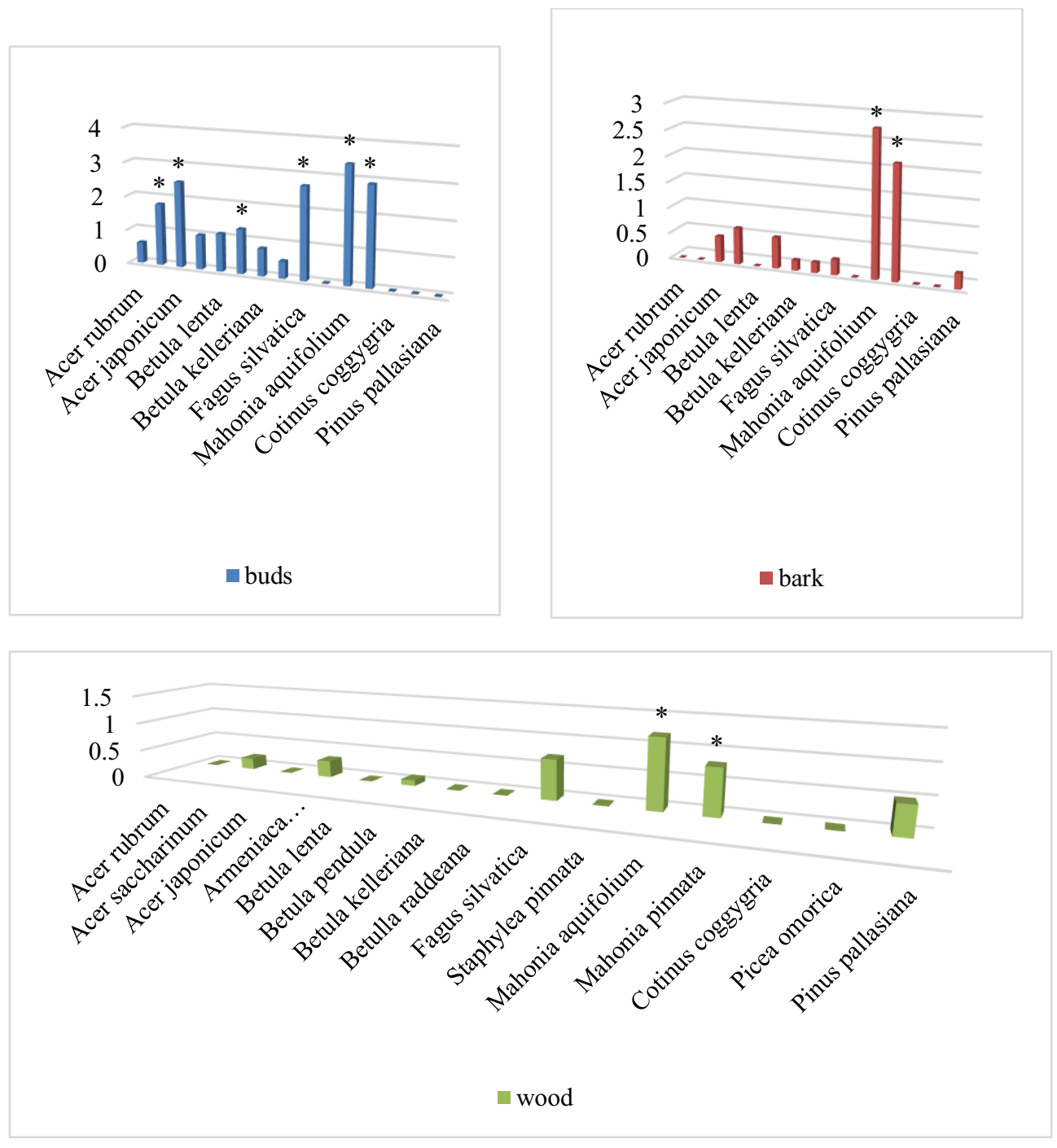

* - significantly at a significance level of $p<0,05$

Fig. 4. Results of artificial freezing of species of ornamental trees and shrubs.

\section{Conclusions}

According to the results of artificial freezing, species of woody plants with high frost resistance were identified: Betula kelleriana, Betula raddeana, Staphylea pinnata, Cotinus Coggygria and Pinus pallasiana. Species of wood above are recommended for creating sustainable landscape compositions for landscaping cities in a temperate continental climate. As a result, sustainable landscape compositions will be of great aesthetic importance and will attract people's attention by flowering, foliage and architectonics of tree crowns. Wood species 
with high frost resistance will contribute to the conservation of biodiversity and decorative green spaces in urban parks in a temperate continental climate.

\section{References}

1. R.M. Karade, Venkata Satish Kuchi, Zehra Salma, Int. Arch. App. Sci. Technol, 8(2), 76-79 (2017)

2. S. Md. Atiqul Haq, J. Environmental Protection, 2, 601-608 (2011) doi:10.4236/jep.2011.25069

3. Y. Avdeyev, I.Desyatova, D.Dolgov, et al., NovaInfo.Ru, 1(58), 145-150 (2017)

4. R.Arora, K.Taulavuori, Frontiers in Environmental Science, 4(44) (2016) doi: 10.3389/fenvs.2016.00044

5. G. Charrier, M.Bonhomme, A.Lacointe, T.Améglio, Int. J Biometeorol, 55(6), 763774 (2011) doi: 10.1007/s00484-011-0470-1

6. A.Kerkhoff, P.Moriarty, M.Weiser, Proceedings of the National Academy of Sciences USA, 111(22), 1-6 (2014) doi: 10.1073 / pnas. 1308932111

7. G. Charrier, J.Ngao, M.Saudreau, et al., Frontiers in Plant Science, 28(6), 259 (2015) doi: 10.3389/fpls.2015.00259

8. G. Charrier, M.Poirier, M. Bonhomme, et al., Tree Physiol, 21, 1-13 (2013) doi: 10.1093/treephys/tpt090

9. Z.Ozherelieva, P.Prudnikov, O.Kurashev, et al., Bulgarian Journal of Agricultural Science, 24 (6), 1053-1058 (2018)

10. Z.Ozherelieva, P.Prudnikov, N.Bogomolova, Proceedings of Latvian Academy of sciences. Section B., 70(2), 88-95 (2016) doi: 10.1515/prolas-2016-0014

11. Z.Ozherelieva, E.Sedov, Proceedings of Latvian Academy of sciences. Section B., 71(3), 127-131 (2017) doi: 10.1515/prolas-2017-0022

12. E.Zolotareva, E.Samoshkin, For. J., 3(327), 33-36 (2012)

13. E.Zolotareva, O.Dubovitskaya, Bulletin of the Oryol SAU, 2(41), 40-45 (2013) http://flower.onego.ru/kustar/mahonia.html

14. Z.Ozherelieva, O.Emelianova, J. For. Sci, 65(6), 218-225 (2019) doi.org/10.17221/8/2019-JFS

15. J.Kreyling, Ecology, 91(7), 1939-1948 (2010) doi: 10.1890/09-1160.1.

16. A.Bolte, T.Czajkowski, T.Kompa, Forestry, 80(4), 413-429 (2007) doi:10.1093/FORESTRY/CPM028

17. N. Saveliev, Genetic potential of resistance of fruit crops to abiotic stressors, 212 (Michurinsk-naukograd Russian Federation 2010) 